\title{
Analysis of the Influence of Organizational Culture, Work Motivation, Entrepreneurial Competence and Social Networks on the Entrepreneurial Performance Through Variable Mediating of Entrepreneurial Orientation in Pesantren Environment in East Java
}

\author{
H.Teman Koesmono. \\ Widya Mandala Catholic University Surabaya
}

\begin{abstract}
This study aims to explore the existence of santripreneurals, manage their independent business in contributing to providing welfare to the general public and especially the people around the boarding school. The results of this study prove that organizational culture has an effect on entrepreneurial orientation but has no effect on entrepreneurial performance, while work motivation, entrepreneurial competence, social networks have an effect on entrepreneurial orientation and entrepreneurial performance. Entrepreneurial orientation affects entrepreneurial performance. The results of this study provide an illustration that the existence of santripreneural is very related to the life of the general public and participates in providing welfare to the community around the pesantren to foster the competences and skills possessed by students in meeting their physical and spiritual needs in order to be balanced. The conditions that exist around the pesantren should be encouraging with the presence of genetic students who pursue their business without abandoning the values of honesty as a santri who adhere to the sciences of religion as a way of life. The role of the government is highly expected to support santripreneurals in carrying out their businesses by providing assistance to the management of MSMEs (Medium, Small, and Micro Enterprises), especially their business development methods.
\end{abstract}

Keywords:Organizational culture, work motivation, entrepreneurial competence, social networks, entrepreneurial orientation and entrepreneurial performance

DOI: $10.7176 /$ RHSS/11-16-07

Publication date:August $31^{\text {st }} 2021$

\section{Background}

The existence of Small and Medium Enterprises (SME) in East Java still influences the economic conditions at both micro and macro levels, therefore building entrepreneurship and managing it seriously requires people who are tough and have special competence in business ventures that are oriented towards the people's economy. The birth of entrepreneurs, both young and senior, shows the growing development of small and medium enterprises at the provincial and district / city levels. Given the heterogeneity of groups of people who are interested in entrepreneurship, it gives hope that independent businesses give interest to individuals to create jobs and can help the government to reduce unemployment. In the existing community, of course, do not miss starting to penetrate the entrepreneurial sector for the sake of social survival in society. In Jawatimur, the existence of Islamic boarding schools as a place or home to study Islam is very much, but at this time it turns out that it is not only to provide knowledge about religion but the need to be able to fulfill social life in society as well as general knowledge to complement its worldly needs. There have been many Islamic boarding schools giving new colors by coloring entrepreneurship and producing products needed by the community as daily necessities of life. The performance of small and medium enterprises requires hard work so that they can develop according to the needs of the community and government. The existence of small and medium enterprises will be related to organizational culture in managing their activities, because organizational culture is a behavior guide for people who carry out entrepreneurial activities. According to Robbins and Judge (2015) organizational culture is a system of sharing meaning by members that differentiates an organization from other organizations. It seems clear that organizations need a system that has a meaning that is agreed upon by all its members to carry out existing activities. A person will feel comfortable in the organization if they have a sense of togetherness directed in behaving in accordance with the existing values agreement. Entrepreneurship certainly requires a strong motivation for entrepreneurs so that what is expected can be realized according to their needs and desires. Everyone must have the motivation so that what is expected can be achieved with the activities carried out and can meet their needs in the future. According to Luthans (1992) motivation is a process that starts with psychological or psychological deficiency or need that activities or drive that is aimed at a goal or incentive. In connection with this opinion, motivation is a process starting with a lack of physiological or psychological needs in the form of behavioral activities or pushing intentions in goals or stimulants. According to Koesmono (2012) Motivating employees or workers is a process so that someone behaves as what the organization or company 
wants in accordance with the types of motivation that exist. When someone has the desire to become an entrepreneur, of course, they must be supported by the competence they have to run the business field of their choice. Competence is the knowledge, attitudes and skills possessed by someone who can be trained through formal or non-formal education. According to Suryana (2003) an entrepreneur needs adequate competence and in accordance with the selected business field so that the direction and goals of his entrepreneurship are in accordance with what is expected in the future. The existence and competitiveness of SMEs (Small and Medium Enterprises) is demanded to always be able to satisfy consumers, this satisfaction will be achieved if the products produced have a strong appeal so that they are liked by the consumers concerned both in quality and in the presence of quantities in the market when needed. Product innovation is one of the strengths of SMEs so that consumers are always interested in buying them because there are many choices that can meet their needs. In addition, business or social networks also have an important meaning for an entrepreneur because through business or social networks, valuable value chains will be obtained and can facilitate the business undertaken by an SME entrepreneur. According to Neneh (2018), Social networking involves the relationship of more than one individual who is connected because of a business relationship or social value so that interactions occur through information or business exchanges. When a person has or is supported by the factors of organizational culture, motivation, entrepreneurial competence and has a social network, it will strengthen his entrepreneurial orientation because with these four variables the stronger the value of entrepreneurial orientation in his soul to become a strong entrepreneur. According to Lumpkin and Dess G. (2001) Entrepreneurial orientation is the efforts of companies to identify market opportunities in order to get the opportunity to get sources both regarding consumers and other interests to support the production process. An entrepreneur is required to improve performance with various strategies chosen so that consumers still have the loyalty to use the goods or products produced. Now work will be achieved as long as several variables that influence it are prepared carefully and accurately, these variables include: organizational culture, work motivation, entrepreneurial competence, social networking and entrepreneurial orientation. According to Siswanto (2016) performance or output will occur when the actions taken have been implemented in the best way. Given the importance of the existence of SMEs as components that can contribute to regional and national economies, the variables mentioned above require special attention for the entrepreneurs.

\section{Theoritical review}

Various types of businesses that exist in the Small and Medium Enterprises (UKM) environment require capital, enthusiasm and never give up in the face of changing economic conditions in society, especially at this time during the Covid 19 pandemic season, both at the middle and upper levels have experienced changes in fulfilling their daily needs. Managing SMEs requires various factors that must be strengthened by the actors, both physical and spiritual. Several variables that must be strengthened in its operations include:

\subsection{Organizational culture}

Culture can describe habits and things that are believed about the true values by a person in directing his behavior to achieve his needs and desires. It can be said that organizational culture is a behavior guide for the actors of the organization to achieve the goals it wants to achieve. Glaser et al. (1987) Organizational culture is often described in terms of being shared. The patterns of beliefs, symbols, rituals and myths that develop over time and serve as the social glue in holding organizations together. Kartono (1994) Agreement forms of behavior that appear in work groups within the company.

\subsection{Work motivation}

All activities carried out by a person are of course to fulfill all the needs and desires of his life at present and in the future. To fulfill the needs of life is not easy and there must be a strong urge and try to find it in the maximum way, this encouragement is in the form of motivation both from himself and from other parties who can be interacted with. Luthans (1992) motivation is a process that starts with physiological or psychological needs which are represented in the form of behavioral activities or motivating intentions in goals or stimulants. Ms Shane and Glinov (2003) Mtivation is The process within a person that affect his or her direction, intensity and persistence of voluntary behavior.

\subsection{Entrepreneurial Competence}

Every person has the competence in himself to carry out activities which are daily activities and must be done to meet his expectations, both material and non-material. Competence will increase if it is sharpened by the experience and knowledge that is owned and has been involved in what is mastered in the field that is occupied. Koesmono (2016) Competence is the ability of a person in a certain field to be able to carry out activities that are mastered and can be obtained through formal and non-formal guidance (experience that has been passed in carrying out certain activities). As an entrepreneur, of course he has competence in the field he is engaged in, it 
is impossible for an entrepreneur to want and be able to enter the business world if he does not have competence in the field concerned. Zahra et al (2009) Entrepreneurial competence is the knowledge, attitudes and skills that are connected to one another that entrepreneurs need to be trained and developed in order to be able to produce the best performance in managing their business.

\subsection{Social networking}

Every activity carried out by an entrepreneur must be able to establish an intimate relationship with his business environment because through the existing network it will add a lot of information obtained for the development of his business. Social networking is a connection between stakeholders who have a relationship with a person's business, either directly or indirectly, for example the community in personal social activities or groups in society. Del Giude and Maggioni (2014) social networking is a relationship between agents of companies to share and obtain and exchange needed resources. Anderson et al (2002) social networking is needed by entrepreneurs to meet the resource needs for their business.

\subsection{Entrepreneurial Orientation}

The enthusiasm of each individual in fulfilling the process of life will vary from person to person, therefore the choice depends on what field the person is going to pursue so that his career will be reflected in his choice. For an entrepreneur, of course, he has prepared himself since he has the inspiration to become an entrepreneur. Drucker, Peter F. (1994) entrepreneurial orientation as a trait, character or traits inherent in someone who has a strong will to bring innovative ideas into the real world of business and can develop them resiliently. Miller and Peter (2011) companies that have entrepreneurial orientation as companies that are able to innovate and dare to take risks. As usual, every entrepreneur will certainly be faced with uncertain conditions regarding future economic conditions, therefore entrepreneurial orientation for SMEs is very much needed so that their business remains sustainable by considering the risks that may occur.

\subsection{Entrepreneurial Performance}

Every entrepreneur must expect to be able to achieve maximum performance as long as his business is still running from time to time. Performance is a measure of the success of an entrepreneur in running his business for a certain period. Performance can be measured quantitatively and qualitatively. Hasibuan (2002) performance is a result of work achieved by a person or organization in carrying out the tasks assigned to him based on his skills, experience and sincerity within a certain time. Meanwhile, Rivai (2005) states that performance is the result or level of success of a person as a whole during a certain period in carrying out a task compared to the possibilities, such as work results, targets, targets or criteria that have been determined in advance and have been mutually agreed.

\subsection{Conceptual Framework}

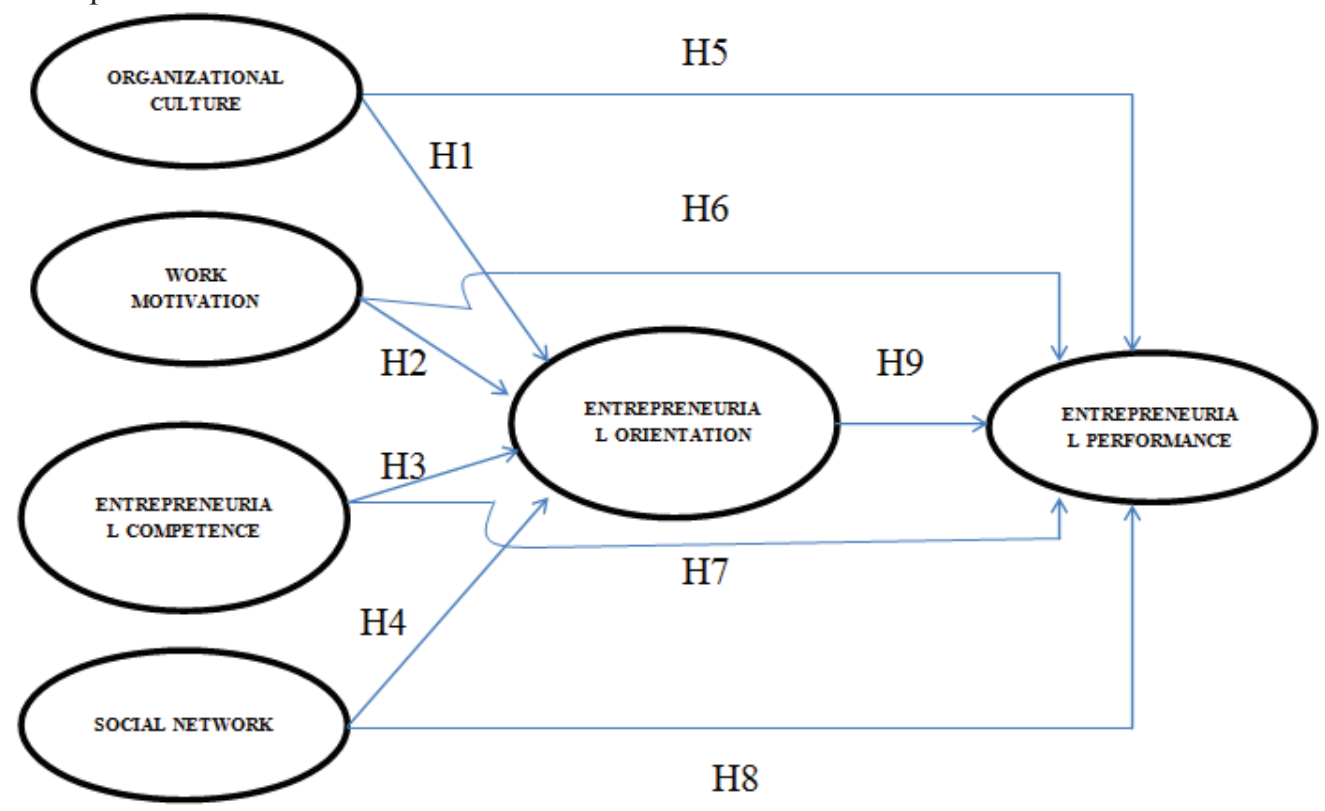

\subsection{Hypothesis}

1. Organizational culture influences entrepreneurial orientation 
2. Work motivation has an effect on entrepreneurial orientation

3. Entrepreneurial competence affects Entrepreneurial Orientation

4. Social Networks affect Entrepreneurial Orientation

5. Organizational culture affects entrepreneurial performance

6. Work motivation has an effect on entrepreneurial performance

7. Entrepreneurial competence affects entrepreneurial performance

8. Social networks affect entrepreneurial performance

9. Entrepreneurial orientation has an effect on entrepreneurial performance

\section{Research methodology}

Based on the background of the problem, it can be classified that this study uses a hypothesis. This research is based on the facts or current conditions (during the Covid 19 pandemic) of SMEs in the Islamic Boarding School in Jawatimur. This study presents the extent to which the influence of organizational culture, work motivation, entrepreneurial competence and social networks on entrepreneurial performance through mediating variables of entrepreneurial orientation.

\subsection{Data types and sources}

The type of data is an interval scale (Likert scale) indicated by the same distance between one number and another, starting from the smallest to the largest number, namely 1 (strongly disagree), 2 (disagree), 3 (neutral), 4 (agree) and 5 (strongly agree). While the data source used is primary by distributing questionnaires to respondents

3.2 The technique of taking and the number of samples

The sampling technique used was random sampling from a population of SME entrepreneurs at Islamic boarding schools in Jawatimur. Sugiyono (2010) The number of samples used is 100-200 people. The number of indicators is 30 so that the sample size uses $30 \times 5=150$ people

\subsection{Technical data analysis}

The data analysis technique will be used using SEM (Structural Equation Modeling) with the AMOS 4.0 program. Ferdinand (2014)

3.4 Regression Equations

$\mathrm{Y} 1=\mathrm{aX} 1+\mathrm{bX} 2+\mathrm{cX} 3+\mathrm{dX} 4$

$\mathrm{Y} 2=\mathrm{eX} 1+\mathrm{fX} 2+\mathrm{gX} 3+\mathrm{hX} 4+\mathrm{iY} 1$

3.5 Variable Identification

Independent variables: Organizational Culture (X1), Work Motivation (2), Entrepreneurial Competence (X3), Social Networking (X4)

The dependent variable: Entrepreneurial Orientation (Y1)

The dependent variable: Entrepreneurial Performance (Y2)

\subsection{Variable Definition:}

1. Organizational Culture are values that are believed to be true and are used as the basis for a person to behave.

2.Motivation is a drive from within and from outside to carry out work activities

3. Entrepreneurship competence is the ability of a person in the field of entrepreneurship that is controlled and can be obtained through formal and non-formal guidance (experiences that have been passed in carrying out entrepreneurial activities).

4.Social network is the relationship between stakeholders who have a relationship with a person's business, either directly or indirectly

5) Entrepreneurship orientation is the nature, character or traits inherent in someone who has a strong will to become an entrepreneur.

6. Entrepreneurial performance is the result or level of success of a person in business activities as a whole during a certain period

4. Research result

\subsection{Respondent Data}

Characteristics of respondents will be described based on age, gender, latest education, marital status, length of business and income per month. The results of the description of the characteristics of the respondents are as follows: 


\begin{tabular}{|c|c|c|c|}
\hline Respondents' profile & Description & Frequency & Percent \\
\hline \multirow{4}{*}{ 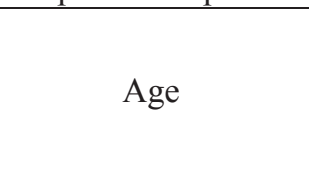 } & $21-30$ years old & 29 & 19.3 \\
\hline & $31-40$ years old & 55 & 36.7 \\
\hline & $41-50$ years old & 37 & 24.7 \\
\hline & More than 50 tah years oldun & 29 & 19.3 \\
\hline \multirow{2}{*}{ Gender } & Male & 107 & 71.3 \\
\hline & Female & 43 & 28.7 \\
\hline \multirow{5}{*}{ Education } & Junior high school & 21 & 14.0 \\
\hline & Senior high school & 64 & 42.7 \\
\hline & Diploma & 16 & 10.7 \\
\hline & Undergraduate (S1) & 46 & 30.7 \\
\hline & Graduate / Postgraduate (S2/S3) & 3 & 2.0 \\
\hline \multirow{3}{*}{ Marital Status } & Single & 19 & 12.7 \\
\hline & Married & 120 & 80.0 \\
\hline & Others & 11 & 7.3 \\
\hline \multirow{5}{*}{$\begin{array}{c}\text { Length of Work in } \\
\text { Bussiness }\end{array}$} & Less than 1 year & 18 & 12.0 \\
\hline & $1-5$ years & 22 & 14.7 \\
\hline & $6-10$ years & 29 & 19.3 \\
\hline & $11-15$ years & 49 & 32.7 \\
\hline & More than 15 years & 32 & 21.3 \\
\hline \multirow{4}{*}{ Turnover per Month } & Less than Rp.10 millions & 22 & 14.7 \\
\hline & Rp.11 - Rp.20 millions & 41 & 27.3 \\
\hline & Rp.21 - Rp.30 millions & 59 & 39.3 \\
\hline & More than Rp.30 millions & 28 & 18.7 \\
\hline
\end{tabular}

4.2Validity

\begin{tabular}{|c|c|c|c|c|}
\hline Variable & Item & Pearson Correlation & Sig. & Decision \\
\hline \multirow{5}{*}{$\begin{array}{l}\text { Organizational Culture } \\
\qquad(\mathrm{X} 1)\end{array}$} & $\mathrm{X} 1.1$ & 0.854 & 0.000 & Valid \\
\hline & $\mathrm{X} 1.2$ & 0.764 & 0.000 & Valid \\
\hline & $\mathrm{X} 1.3$ & 0.797 & 0.000 & Valid \\
\hline & $\mathrm{X} 1.4$ & 0.730 & 0.000 & Valid \\
\hline & $\mathrm{X} 1.5$ & 0.699 & 0.000 & Valid \\
\hline \multirow{5}{*}{ Work Motivation (X2) } & $\mathrm{X} 2.1$ & 0.760 & 0.000 & Valid \\
\hline & $\mathrm{X} 2.2$ & 0.844 & 0.000 & Valid \\
\hline & $\mathrm{X} 2.3$ & 0.756 & 0.000 & Valid \\
\hline & $\mathrm{X} 2.4$ & 0.795 & 0.000 & Valid \\
\hline & $\mathrm{X} 2.5$ & 0.772 & 0.000 & Valid \\
\hline \multirow{5}{*}{$\begin{array}{c}\text { Entrepreneurial } \\
\text { Competence (X3) }\end{array}$} & X3.1 & 0.744 & 0.000 & Valid \\
\hline & $\mathrm{X} 3.2$ & 0.808 & 0.000 & Valid \\
\hline & X3.3 & 0.795 & 0.000 & Valid \\
\hline & X3.4 & 0.713 & 0.000 & Valid \\
\hline & $\mathrm{X} 3.5$ & 0.737 & 0.000 & Valid \\
\hline \multirow{5}{*}{ Social Network (X4) } & $\mathrm{X} 4.1$ & 0.798 & 0.000 & Valid \\
\hline & $\mathrm{X} 4.2$ & 0.775 & 0.000 & Valid \\
\hline & $\mathrm{X} 4.3$ & 0.839 & 0.000 & Valid \\
\hline & $\mathrm{X} 4.4$ & 0.840 & 0.000 & Valid \\
\hline & $\mathrm{X} 4.5$ & 0.784 & 0.000 & Valid \\
\hline \multirow{5}{*}{$\begin{array}{l}\text { Entrepreneurial } \\
\text { Orientation (Y1) }\end{array}$} & Y1.1 & 0.741 & 0.000 & Valid \\
\hline & Y1.2 & 0.816 & 0.000 & Valid \\
\hline & Y1.3 & 0.793 & 0.000 & Valid \\
\hline & Y1.4 & 0.706 & 0.000 & Valid \\
\hline & Y1.5 & 0.780 & 0.000 & Valid \\
\hline \multirow{4}{*}{$\begin{array}{c}\text { Entrepreneurial } \\
\text { Performance (Y2) }\end{array}$} & Y2.1 & 0.709 & 0.000 & Valid \\
\hline & Y2.2 & 0.781 & 0.000 & Valid \\
\hline & Y2.3 & 0.811 & 0.000 & Valid \\
\hline & Y2.4 & 0.720 & 0.000 & Valid \\
\hline
\end{tabular}




\begin{tabular}{|c|c|c|c|c|}
\hline Variable & Item & Pearson Correlation & Sig. & Decision \\
\hline & Y2.5 & 0.757 & 0.000 & Valid \\
\hline
\end{tabular}

The table shows that the correlation value for each measurement item on all variables has a range between 0.699-0.854, so that all statement items have a correlation value greater than 0.361 and are also significant at the real level $\alpha 5 \%$ (Sig. $\leq 5 \%$ ). Thus it can be concluded that all statement items used to measure the variables of organizational culture, work motivation, entrepreneurial competence, social networks, entrepreneurial orientation, and entrepreneurial performance are valid and can be used for further analysis.

The next test is the reliability test, which is used to determine the reliability or consistency of variable measurements. Reliability testing was carried out using the cronbach's alpha technique, according to Malholtra, the questionnaire was declared reliable if it produced a cronbach's alpha value greater than 0.60, Solimun (2017)

4.3 Reliability

\begin{tabular}{|l|c|c|c|}
\hline Variable & Cronbach's $\alpha$ & No. of items & Decision \\
\hline Organizational culture $\left(\mathrm{X}_{1}\right)$ & 0,824 & 5 & Reliable \\
Work motivation $\left(\mathrm{X}_{2}\right)$ & 0,844 & 5 & Reliable \\
Entrepreneurial competence $\left(\mathrm{X}_{3}\right)$ & 0,808 & 5 & Reliable \\
Social network $\left(\mathrm{X}_{4}\right)$ & 0,857 & 5 & Reliable \\
Entrepreneurial orientation $\left(\mathrm{Y}_{1}\right)$ & 0,818 & 5 & Reliable \\
Entrepreneurial performance $\left(\mathrm{Y}_{2}\right)$ & 0,809 & 5 & Reliable \\
\hline
\end{tabular}

The table shows that the Cronbach's alpha value for all variables has a value greater than 0.60 , so it is concluded that the arrangement of statement items used to measure the variables of organizational culture, work motivation, entrepreneurial competence, social networking, entrepreneurial orientation, and entrepreneurial performance can be concluded. declared reliable and can be trusted as a consistent measuring tool.

\subsection{Variable Description}

Descriptive data analysis is to describe the results of the analysis of respondents 'answers by describing the respondents' assessments based on the collected questionnaire data. In the analysis of the description of each research variable, the average respondent's responses to each indicator and overall on each research variable will be explained.

The results of the average respondent's responses to each indicator and variable can then be categorized using the class interval formula guide as follows:

Interval $=\frac{\text { Range }}{\text { interval }}=\frac{\text { highest }- \text { lowest }}{\text { interval }}=\frac{5-1}{5}=0,80$

The resulting class interval is 0.80 , this value is then used as a guide to determine the category based on the average interval, which is as follows:
$1,00<$ mean $\leq$
1,80 : strongly diasgree(SD) / very poor
$1,80<$ mean $\leq$
2,60 : disagree(D) / poor
$2,60<$ mean $\leq$
3,40 : neutral $(\mathrm{N}) /$ fair
$3,40<$ mean $\leq$
4,20 : agree(A)/good
$4,20<$ mean $\leq$
5,00 : strongly agree(SA) / excellent

The description of the assessment of SME entrepreneurs at Islamic boarding schools in East Java who were respondents in this study on the variables of organizational culture, work motivation, entrepreneurial competence, social networking, entrepreneurial orientation, and entrepreneurial performance are presented in the following table: 
Average respondents' answers

\begin{tabular}{|c|c|c|c|c|c|c|c|c|}
\hline \multirow{2}{*}{ Variable } & \multirow{2}{*}{ Indicator } & \multicolumn{5}{|c|}{ Frequency } & \multirow{2}{*}{ Mean } & \multirow{2}{*}{ Level } \\
\hline & & SD & $\mathrm{D}$ & $\mathrm{N}$ & $\mathrm{A}$ & $\mathrm{SA}$ & & \\
\hline \multirow{6}{*}{$\begin{array}{l}\text { Organizational } \\
\text { culture(X1) }\end{array}$} & X1.1 & 0 & 28 & 48 & 46 & 28 & 3.49 & good \\
\hline & $\mathrm{X} 1.2$ & 0 & 0 & 47 & 69 & 34 & 3.91 & good \\
\hline & $\mathrm{X} 1.3$ & 0 & 13 & 53 & 57 & 27 & 3.65 & good \\
\hline & X1.4 & 0 & 16 & 50 & 60 & 24 & 3.61 & good \\
\hline & $\mathrm{X} 1.5$ & 0 & 0 & 30 & 78 & 42 & 4.08 & good \\
\hline & & & & & & & 3.75 & good \\
\hline \multirow{6}{*}{$\begin{array}{c}\text { Work } \\
\text { motivation }(\mathrm{X} 2)\end{array}$} & X2.1 & 0 & 20 & 62 & 56 & 12 & 3.40 & fair \\
\hline & X2.2 & 0 & 19 & 37 & 65 & 29 & 3.69 & good \\
\hline & $\mathrm{X} 2.3$ & 0 & 15 & 65 & 56 & 14 & 3.46 & good \\
\hline & $\mathrm{X} 2.4$ & 0 & 15 & 62 & 63 & 10 & 3.45 & good \\
\hline & $\mathrm{X} 2.5$ & 0 & 0 & 42 & 70 & 38 & 3.97 & good \\
\hline & & & & & & & 3.60 & good \\
\hline \multirow{6}{*}{$\begin{array}{c}\text { Entrepreneurial } \\
\text { competence (X3) }\end{array}$} & X3.1 & 0 & 11 & 62 & 62 & 15 & 3.54 & good \\
\hline & X3.2 & 0 & 22 & 53 & 45 & 30 & 3.55 & good \\
\hline & X3.3 & 0 & 11 & 60 & 56 & 23 & 3.61 & good \\
\hline & X3.4 & 0 & 14 & 68 & 54 & 14 & 3.45 & good \\
\hline & X3.5 & 0 & 10 & 42 & 73 & 25 & 3.75 & good \\
\hline & & & & & & & 3.58 & good \\
\hline \multirow{6}{*}{$\begin{array}{l}\text { Social network } \\
\text { (X4) }\end{array}$} & $\mathrm{X} 4.1$ & 0 & 14 & 52 & 60 & 24 & 3.63 & good \\
\hline & $\mathrm{X} 4.2$ & 0 & 29 & 60 & 45 & 16 & 3.32 & fair \\
\hline & $\mathrm{X} 4.3$ & 0 & 7 & 51 & 59 & 33 & 3.79 & good \\
\hline & X4.4 & 0 & 22 & 51 & 59 & 18 & 3.49 & good \\
\hline & X4.5 & 0 & 0 & 35 & 77 & 38 & 4.02 & good \\
\hline & & & & & & & 3.65 & good \\
\hline \multirow{6}{*}{$\begin{array}{l}\text { Entrepreneurial } \\
\text { orientation (Y1) }\end{array}$} & Y1.1 & 0 & 29 & 50 & 48 & 23 & 3.43 & good \\
\hline & Y1.2 & 0 & 30 & 54 & 57 & 9 & 3.30 & fair \\
\hline & Y1.3 & 0 & 12 & 73 & 53 & 12 & 3.43 & good \\
\hline & Y1.4 & 0 & 13 & 44 & 63 & 30 & 3.73 & good \\
\hline & Y1.5 & 0 & 0 & 27 & 79 & 44 & 4.11 & good \\
\hline & & & & & & & 3.60 & good \\
\hline \multirow{6}{*}{$\begin{array}{c}\text { Entrepreneurial } \\
\text { performance (Y2) }\end{array}$} & Y2.1 & 0 & 0 & 51 & 73 & 26 & 3.83 & good \\
\hline & Y 2.2 & 0 & 0 & 49 & 75 & 26 & 3.85 & good \\
\hline & Y 2.3 & 0 & 10 & 44 & 72 & 24 & 3.73 & good \\
\hline & Y 2.4 & 0 & 0 & 42 & 76 & 32 & 3.93 & good \\
\hline & Y2.5 & 0 & 17 & 65 & 55 & 13 & 3.43 & good \\
\hline & & & & & & & 3.75 & good \\
\hline
\end{tabular}

The average value of the respondents' answers to the research variables is as follows:

Organizational Culture $(\mathrm{X} 1)=4.50$, Work Motivation $(\mathrm{X} 2)=4.30$, Entrepreneurial Competence $(\mathrm{X} 3)=$ 4.30, Social Networking $(\mathrm{X} 4)=4.40$, Entrepreneurial Orientation $(\mathrm{Y} 1)=4.30$, Entrepreneurial Performance $(\mathrm{Y} 2)=4.50$ all Excellent or in general the answers lead to positive things to the questions posed by researchers.

4.4 Multivariate Normality

In SEM, the multivariate normality test is carried out with the value of the critical ratio (c.r.) in the multivariate kurtosis section, the value of c.r. this is also called the $\mathrm{Z}$-value. If the $\mathrm{Z}$-value is greater than the critical value, the data distribution is not normal, on the other hand, if the $\mathrm{Z}$-value is smaller than the critical value, the data distribution is normal. The critical value can be determined based on the significance level of $0.05(5 \%)$ which is equal to 1.96 .

Multivariate Normality

\begin{tabular}{|c|c|c|c|}
\hline Test & Kurtosis & c.r multivariate & Conclusion \\
\hline $\begin{array}{c}\text { Multivariate } \\
\text { normality }\end{array}$ & 0.207 & 0.029 & $\begin{array}{c}\text { c.r. are in the range of } \pm 1.96, \text { so that } \\
\text { the multivariate data are normally } \\
\text { distributed }\end{array}$ \\
\hline
\end{tabular}

The results of the normality test showed that the multivariate c.r was 0.029 which was in the range -1.96 to +1.96 at the $5 \%$ significance level, so it could be concluded that the multivariate data were normally distributed. 
Thus, the analysis can be continued to the next stage.

\subsection{Multivariate Outlier}

Multivariate outlier detection can be done using Mahalanobis Distance (Mahalanobis d-Squared), the principle is that Mahalanobis d-Squared is a measure to evaluate the position of each observation compared to the center of all observations on a set of variables (Hair et al., 2014). The resulting d-Squared mahalanobis was evaluated using $\chi^{2}$ (chi-square) in degrees of freedom equal to the number of indicators used in the SEM model. If there are observations that produce a Mahalanobis d-Squared value greater than the chi-square value at $\mathrm{df}=$ number of indicators and a significance level of 0.001 , then these observations are identified as multivariate outliers. The result of the calculation of the chi-square table with 30 degrees of freedom (number of indicators $=30$ ) is 59.70 . The results of the detection of multivariate outliers based on the results of data processing show that all observations have a d-squared mahalonobis value between 36.56-47.22 smaller than the chi-square limit of 59.70 table, so none of the observations (respondents) are indicated as outliers and all of them can be. used for analysis. Model Structure Analysis

Measurement model analysis is also called the confirmatory factor analysis (CFA) test. CFA serves to identify whether the indicators are constructs of the research variables or in other words, these indicators are one unit or have undimensionality in reflecting the construct. The CFA test is done by testing the measurement model fit.

Fit measure for the measurement model

\begin{tabular}{|c|c|c|c|c|c|c|}
\hline \multirow{2}{*}{\multicolumn{2}{|c|}{ Fit Measure }} & \multirow{2}{*}{$\begin{array}{c}\begin{array}{c}\text { Critical } \\
\text { Value }\end{array} \\
>0.05\end{array}$} & \multicolumn{2}{|c|}{ Initial Model } & \multicolumn{2}{|c|}{ Revised Model } \\
\hline & & & Index yalue & Decicion & Index & Decicion \\
\hline $\begin{array}{l}\text { Absolute Fit } \\
\text { Indices }\end{array}$ & $\begin{array}{l}\text { Probability } \\
\text { Cmin/DF } \\
\text { GFI } \\
\text { RMSEA } \\
\end{array}$ & $\begin{array}{l}>0.05 \\
\leq 3.00 \\
\geq 0.90 \\
\leq 0.08\end{array}$ & $\begin{array}{l}0.022 \\
1.149 \\
0.840 \\
0.032 \\
\end{array}$ & $\begin{array}{l}\text { Poor fit } \\
\text { Good fit } \\
\text { Marginal fit } \\
\text { Good fit }\end{array}$ & $\begin{array}{l}0.072 \\
1.107 \\
0.848 \\
0.027 \\
\end{array}$ & $\begin{array}{l}\text { Good fit } \\
\text { Good fit } \\
\text { Marginal fit } \\
\text { Good fit }\end{array}$ \\
\hline $\begin{array}{c}\text { Incremental Fit } \\
\text { Indices }\end{array}$ & $\begin{array}{l}\text { CFI } \\
\text { TLI }\end{array}$ & $\begin{array}{l}\geq 0.95 \\
\geq 0.95\end{array}$ & $\begin{array}{l}0.957 \\
0.952 \\
\end{array}$ & $\begin{array}{l}\text { Good fit } \\
\text { Good fit }\end{array}$ & $\begin{array}{l}0.969 \\
0.966 \\
\end{array}$ & $\begin{array}{l}\text { Good fit } \\
\text { Good fit }\end{array}$ \\
\hline $\begin{array}{l}\text { Parsimony Fit } \\
\text { Indices }\end{array}$ & AGFI & $\geq 0.90$ & 0.809 & Marginal fit & 0.818 & Marginal fit \\
\hline
\end{tabular}

The table shows the results of the evaluation of the suitability of the measurement model (revised model) producing criteria that are all acceptable (good fit and marginal fit), and are more fit than the initial model, so the measurement model can be accepted.

4.6 Analysis of the direct effect

The next stage of structural model analysis is the testing of structural relationships in the direct effect path, namely examining the estimated relationship parameters between variables that represent each theoretical hypothesis. The hypothesis can be accepted if the path parameters are statistically significant with the direction of influence predicted, meaning that the path parameters must be greater than zero for the positive direction and less than zero for the negative direction. Hair et al. (2014)

In testing structural relationships, hypothesis testing is carried out to test the significance of the influence between variables, using the critical ratio $(\mathrm{CR})$ value and the probability value (p-value). If the $\mathrm{CR}$ value is $\geq$ 1.96 or the $p$-value $\leq 5 \%$ significance level is significant or not, then it is decided that there is a significant influence between these variables.

Following are the results of testing structural relationships in order to test each research hypothesis based on the SEM output: 
Summary of the direct effect

\begin{tabular}{|c|c|c|c|c|c|c|}
\hline Hip. & \multicolumn{3}{|l|}{ Structural relationship } & $\begin{array}{c}\text { Std. } \\
\text { Estimate }\end{array}$ & C.R. & $\begin{array}{c}\mathrm{P} \\
\text { value }\end{array}$ \\
\hline $\mathrm{H}_{1}$ & Organizational culture & $\rightarrow$ & Entrepreneurial orientation & 0.379 & 3.650 & $0.000^{* *}$ \\
\hline $\mathrm{H}_{2}$ & Work motivation & $\rightarrow$ & Entrepreneurial orientation & 0.274 & 2.728 & $0.006^{* *}$ \\
\hline $\mathrm{H}_{3}$ & Entrepreneurial competence & $\rightarrow$ & Entrepreneurial orientation & 0.426 & 3.940 & $0.000^{* *}$ \\
\hline $\mathrm{H}_{4}$ & Social network & $\rightarrow$ & Entrepreneurial orientation & 0.426 & 4.176 & $0.000^{* *}$ \\
\hline $\mathrm{H}_{5}$ & Organizational culture & $\rightarrow$ & Entrepreneurial performance & 0.088 & 0.800 & $0.424^{\text {n.s }}$ \\
\hline $\mathrm{H}_{6}$ & Work motivation & $\rightarrow$ & Entrepreneurial performance & 0.273 & 2.617 & $0.009^{* *}$ \\
\hline $\mathrm{H}_{7}$ & Entrepreneurial competence & $\rightarrow$ & Entrepreneurial performance & 0.266 & 2.201 & $0.028^{*}$ \\
\hline $\mathrm{H}_{8}$ & Social network & $\rightarrow$ & Entrepreneurial performance & 0.286 & 2.391 & $0.017^{*}$ \\
\hline $\mathrm{H}_{9}$ & Entrepreneurial orientation & $\rightarrow$ & Entrepreneurial performance & 0.373 & 3.099 & $0.002^{* *}$ \\
\hline $\begin{array}{l}* . \mathrm{Si} \\
* * . \mathrm{S}\end{array}$ & $\begin{array}{l}\text { ificant at the } 0.05 \text { level } \\
\text { gnificant at the } 0.01 \text { level }\end{array}$ & & Not significant & & & \\
\hline
\end{tabular}

Based on this table, it can be explained as follows:

a. The estimation result of the parameter of the influence of organizational culture on entrepreneurial orientation shows a significant effect with a CR value of 3,650 (greater than 1.96) and a significance value (p-value) of 0,000 (less than the $5 \%$ real level). The resulting coefficient of influence is 0.379 (positive), meaning that the higher the organizational culture, the higher the entrepreneurial orientation. Thus, the first hypothesis which states that organizational culture has a positive and significant effect on entrepreneurial orientation of SME entrepreneurs at Islamic boarding schools in East Java is accepted (H1 accepted).

b. The estimation result of the parameter of the effect of work motivation on entrepreneurial orientation also shows a significant effect with a CR value of 2.728 (greater than 1.96) and a significance value (pvalue) of 0.006 (smaller than the $5 \%$ real level). The resulting coefficient of influence is 0.274 (positive), meaning that the higher the work motivation, the higher the entrepreneurial orientation. Thus, the second hypothesis which states that work motivation has a positive and significant effect on entrepreneurial orientation of SME entrepreneurs at Islamic boarding schools in East Java is also acceptable (H2 accepted).

c. The estimation result of the parameter of the influence of entrepreneurial competence on entrepreneurial orientation also shows a significant effect with a CR value of 3,940 (greater than 1.96) and a significance value (p-value) of 0,000 (less than the $5 \%$ real level). The resulting coefficient of influence is 0.426 (positive), meaning that the higher the entrepreneurial competence, the higher the entrepreneurial orientation. Thus, the third hypothesis which states that entrepreneurial competence has a positive and significant effect on entrepreneurial orientation of SME entrepreneurs at Islamic boarding schools in East Java is also acceptable (H3 accepted).

d. The estimation results of the parameters of the influence of social networks on entrepreneurial orientation also show a significant effect with a $\mathrm{CR}$ value of 4.176 (greater than 1.96) and a significance value (p-value) of 0.000 (less than the $5 \%$ real level). The resulting coefficient of influence is 0.426 (positive), meaning that the higher the social network, the higher the entrepreneurial orientation. Thus, the fourth hypothesis which states that social networks have a positive and significant effect on entrepreneurial orientation of SME entrepreneurs at Islamic boarding schools in East Java is also acceptable (H4 accepted).

e. The estimation result of the parameter of the influence of organizational culture on entrepreneurial performance shows an insignificant effect with a $\mathrm{CR}$ value of 0.800 (less than 1.96) and a significance value (p-value) of 0.424 (smaller than the $5 \%$ real level). The resulting coefficient of influence is only 0.088 , meaning that the higher the organizational culture is not able to have a real impact on increasing entrepreneurial performance. Thus, the fifth hypothesis which states that organizational culture has a positive and significant effect on entrepreneurial performance of SME entrepreneurs at Islamic boarding schools in East Java, cannot be accepted (H5 rejected).

f. The estimation result of the parameter of the effect of work motivation on entrepreneurial performance shows a significant effect with a $\mathrm{CR}$ value of 2,617 (greater than 1.96) and a significance value (p-value) of 0.009 (smaller than the $5 \%$ real level). The resulting coefficient of influence is 0.273 (positive), meaning that the higher the work motivation, the higher the entrepreneurial performance. Thus, the sixth hypothesis which states that work motivation has a positive and significant effect on entrepreneurial performance of SME entrepreneurs at Islamic boarding schools in East Java is acceptable (H6 accepted).

g. The estimation result of the parameter of the influence of entrepreneurial competence on entrepreneurial performance also shows a significant effect with a CR value of 2.201 (greater than 1.96) and a 
significance value (p-value) of 0.028 (smaller than the $5 \%$ real level). The resulting coefficient of influence is 0.266 (positive), meaning that the higher the entrepreneurial competence, the higher the entrepreneurial performance. Thus, the seventh hypothesis which states that entrepreneurial competence has a positive and significant effect on entrepreneurial performance of SME entrepreneurs at Islamic boarding schools in East Java is also acceptable (H7 accepted).

h. The estimation result of the parameter of the influence of social networks on entrepreneurial performance also shows a significant effect with a CR value of 2,391 (greater than 1.96) and a significance value (p-value) of 0.017 (smaller than the 5\% real level). The resulting coefficient of influence is 0.286 (positive), meaning that the higher the social network, the higher the entrepreneurial performance. Thus, the eighth hypothesis which states that social networks have a positive and significant effect on entrepreneurial performance of SME entrepreneurs at Islamic boarding schools in East Java is also acceptable (H8 accepted).

i. The estimation result of the parameter of the influence of entrepreneurial orientation on entrepreneurial performance also shows a significant effect with a CR value of 3.099 (greater than 1.96) and a significance value (p-value) of 0.002 (less than the 5\% real level). The resulting coefficient of influence is 0.373 (positive), meaning that the higher the entrepreneurial orientation, the higher the entrepreneurial performance. Thus, the ninth hypothesis which states that entrepreneurship orientation has a positive and significant effect on entrepreneurial performance of SME entrepreneurs at Islamic boarding schools in East Java is also acceptable (H9 accepted).

\subsection{Analysis of the indirect effect}

The next stage of structural model analysis is testing of structural relationships on the path of the indirect effect. Hypothesis testing to test the significance of this indirect effect is carried out in the same way, namely using the critical ratio (CR) value and the probability value ( $p$-value). If the CR value is $\geq 1.96$ or the $p$-value $\leq 5 \%$ significant level is significant or not, then it is decided that there is a significant effect.

After testing the significance of the effect of mediation, the next step is to find out the nature of the mediation. Ghozali (2011) explained that detecting the nature of mediation can be seen from the effect of the mediation, if the direct effect of exogenous variables on endogenous variables is significant, and the indirect effect through intervening variables is also through significant pathways, then it is said to be partially mediated. Conversely, if the direct effect of exogenous variables on endogenous variables is not significant, while the indirect effect through intervening variables through a significant pathway, then it is said to be fully mediation or perfect medation.

Following are the results of testing structural relationships in order to test the indirect effect based on the SEM output

The indirect effect testing

\begin{tabular}{|l|c|c|c|l|}
\hline Indirect effect & Std. Estimate & C.R. & P-value & Type of mediator \\
\hline $\mathrm{X}_{1} \rightarrow \mathrm{Y}_{1} \rightarrow \mathrm{Y}_{2}$ & 0.141 & 2.311 & $0.021^{*}$ & Fullymediation \\
$\mathrm{X}_{2} \rightarrow \mathrm{Y}_{1} \rightarrow \mathrm{Y}_{2}$ & 0.102 & 1.988 & $0.048^{*}$ & Partially mediation \\
$\mathrm{X}_{3} \rightarrow \mathrm{Y}_{1} \rightarrow \mathrm{Y}_{2}$ & 0.159 & 2.385 & $0.018^{*}$ & Partially mediation \\
$\mathrm{X}_{4} \rightarrow \mathrm{Y}_{1} \rightarrow \mathrm{Y}_{2}$ & 0.159 & 2.446 & $0.015^{*}$ & Partially mediation \\
\hline $\mathrm{X}_{1}:$ organizational culture & $\mathrm{Y}_{1}:$ entrepreneurial orientation \\
$\mathrm{X}_{2}:$ work motivation & \multicolumn{3}{c|}{$\mathrm{Y}_{2}:$ entrepreneurial performance } \\
$\mathrm{X}_{3}:$ entrepreneurial competence & \multirow{3}{*}{. Significant at the 0.05 level } \\
$\mathrm{X}_{4}:$ social network &
\end{tabular}

Based on the table above, it can be explained that the results of the indirect path significance test $\mathrm{X} 1 \rightarrow \mathrm{Y} 1 \rightarrow \mathrm{Y} 2$ show a significant effect with a CR value of 2,311 (greater than 1.96) and a significance value ( $\mathrm{p}$ value) of 0.021 (smaller than the real level. 5\%). Thus, organizational culture affects entrepreneurial performance through entrepreneurial orientation mediation of SME entrepreneurs at Islamic boarding schools in East Java. The nature of the mediator is known to be fully mediation, meaning that increasing entrepreneurial performance cannot only rely on a strong organizational culture, but must be supported by a high entrepreneurial orientation.

The results of the indirect path significance test $\mathrm{X} 2 \rightarrow \mathrm{Y} 1 \rightarrow \mathrm{Y} 2$ also showed a significant effect with a CR value of 1.988 (greater than 1.96) and a significance value (p-value) of 0.048 (smaller than the $5 \%$ real level). Thus, work motivation also affects entrepreneurial performance through entrepreneurial orientation mediation of SME entrepreneurs at Islamic boarding schools in East Java. The nature of the mediator is known to be partially mediation, which means that increasing entrepreneurial performance can only be done by increasing work motivation, but if it is also supported by an increase in entrepreneurial orientation, then entrepreneurial performance can be further increased.

The results of the indirect path significance test $\mathrm{X} 3 \rightarrow \mathrm{Y} 1 \rightarrow \mathrm{Y} 2$ also showed a significant effect with a CR 
value of 2,385 (greater than 1.96) and a significance value (p-value) of 0.018 (less than the $5 \%$ real level). Thus, entrepreneurial competence also affects entrepreneurial performance through entrepreneurial orientation mediation of SME entrepreneurs at Islamic boarding schools in East Java. The nature of the mediator is known to be partially mediation, which means that increasing entrepreneurial performance can only be done by increasing entrepreneurial competence, but if it is also supported by an increase in entrepreneurial orientation, then entrepreneurial performance can be further increased.

The results of the indirect path significance test $\mathrm{X} 4 \rightarrow \mathrm{Y} 1 \rightarrow \mathrm{Y} 2$ also showed a significant effect with a CR value of 2.446 (greater than 1.96) and a significance value (p-value) of 0.015 (smaller than the 5\% real level). Thus, social networking also affects entrepreneurial performance through entrepreneurial orientation mediation of SME entrepreneurs at Islamic boarding schools in East Java. It is known that the nature of the mediator is partially mediation, which means that increasing entrepreneurial performance can only be done by expanding social networks, but if it is also supported by an increase in entrepreneurial orientation, then entrepreneurial performance can be further increased.

\subsection{Hypotesis result}

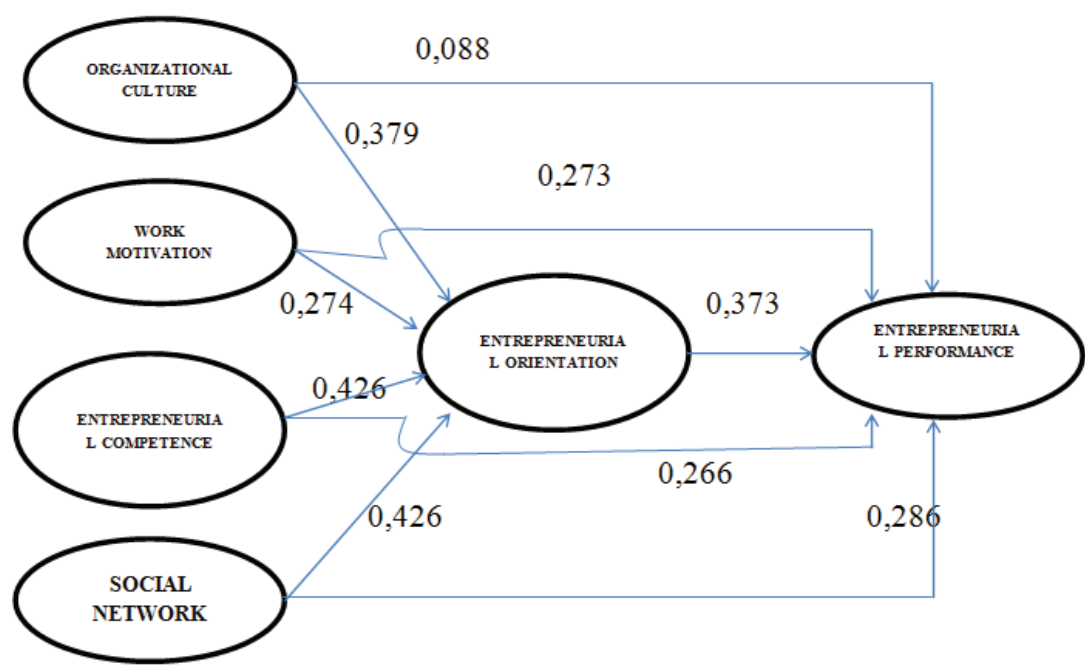

Equation result

$\mathrm{Y} 1=0,379 \mathrm{X} 1+0,274 \mathrm{X} 2+0,426 \mathrm{X} 3+0,426 \mathrm{X} 4$

$\mathrm{Y} 2=0,088 \mathrm{X} 1+0,273 \mathrm{X} 2+0,266 \mathrm{X} 3+0,286 \mathrm{X} 4+0,373 \mathrm{Y} 1$

4.9 Discussion of research results

1. Organizational culture affects entrepreneurial orientation, the results of this study support research conducted by Utama (2017), Santoso et al. (2020), Victor (2011), Angelen et al (2019)

2. Work motivation has an effect on entrepreneurial orientation, the results of this study support the research that has been done by Kusnilawati and Nurhidayati (2020).

3. Entrepreneurial competence affects entrepreneurial orientation, the results of this study support research conducted by Mariani and Wulantari (2020), Santoso et al. (2020), Wickramaratne et al (2014)

4. Social networks affect entrepreneurial orientation, the results of this study support the research conducted by Santoso et al. (2020), Parida et al. (2010)

5. Organizational culture has no effect on entrepreneurial performance, the results of this study support research conducted by Rante (2010) but do not support research conducted by Yuswani (2016), Victor (2011)

6. Work motivation affects entrepreneurial performance, the results of this study support the results of research by Basuki (20027), Sumantri (2013), Koesmono (2019) and rejecting research conducted by Trihudiyatmono and Purwanto (2018)

7. Entrepreneurial competence affects entrepreneurial performance, the results of this study support research conducted by Ludiya (2020), Trihudiyatmono and Purwanto (2018), Kusnilawati and Nurhidayati (2020)

8. Social networks affect entrepreneurial performance, the results of this study support research conducted by Utama (2017), Santoso et al. (2020), Chima and Amodu (2017), Parida et al (2010)

9. Entrepreneurial orientation affects entrepreneurial performance, the results of this study support research conducted by Purwanto and Trihudijatmanto (2018), Koesmono (2019) but do not support the results of research by Toyib (2017), Chein (2014), 


\section{Conclusion}

1. Organizational culture has an effect on entrepreneurial orientation, this shows that culture is a factor that plays a role in improving the entrepreneurial orientation of santripreneurals in doing independent efforts to meet their daily needs while pursuing religious values that must be practiced. However, the presence of organizational culture has no effect on entrepreneurial performance, this has been embedded in a strong entrepreneurial work culture and has an indirect effect through entrepreneurial orientation, this is evidenced by the presence of entrepreneurial orientation factors as a mediating variable in the influence of organizational culture on entrepreneurial performance.

2. Work motivation affects entrepreneurial orientation and entrepreneurial performance, illustrating that students have strong motivation both from themselves and from the external environment to carry out entrepreneurship that is occupied by the values of the pesantren in their environment.

3. Entrepreneurial competence affects entrepreneurial orientation and entrepreneurial performance. This is in line with the entrepreneurial abilities, knowledge and skills of santri in the modern era that students must also study efforts that support the welfare of society.

4.Social networks have an effect on entrepreneurial orientation and entrepreneurial performance, it is only natural that a santripreneural should build social networks so that all efforts made in building small and medium enterprises are able to meet the needs of the general public in meeting their daily needs and the wider social networks give hope. the wider the market reach they have.

5. Entrepreneurial orientation affects entrepreneurial performance, illustrating that the importance of entrepreneurial orientation factors in supporting entrepreneurial performance is because entrepreneurial orientation is the readiness of students to face challenging markets to face new and existing competitors in addition to the main awareness that business conditions will always be faced. With uncertain conditions going forward, therefore it takes a strong mentality and is ready to face the pressures of changes in the market.

From these conclusions, it can be seen that there are encouraging developments for the life of pesantren in East Java, namely the growth of economic strengthening and improvement of community welfare through the pesantren area (UMKM actors from students and alumni). The OPOP (One Pesantren, One Product) program provides strengthening to Santripreuneral through: 1) The empowerment program for students with the aim of fostering an understanding of skills in producing unique sharia products that are oriented towards utilization and profit sharing. 2) Empowerment of the pesantren economy through Islamic boarding school cooperatives with the aim of producing superior halal products that can be accepted by local, national and international markets 3) Sociopreneural, empowering pesantren alumni who are synergized with the general public accompanied by various social conditions, innovation, creativity based on digital technology .

5.2 Research variable indicators

Organizational culture

1. Work enthusiasm

2. Employee work discipline

3. Increase religious activities

4. Family relations with employees

5. Attention to the social environment

Work motivation

1. Loves challenges

2. Trying to be the best

3. Dare to face risks

4.Orientation on change

5. Market development

Entrepreneurial Competence

1. Knowledge

2. Skills

3. Attitude

4. Planning

5. Organizing

Social network

1. Relationships with suppliers

2. Relationship with the dealer 
3. Relationships with competitors

4. Relationships with family

5. Relationships with peers

Entrepreneurial Orientation

1. Product innovation

2. Get close to consumers

3. Ready to face competitors

4. Ready to face risks

5. Calculate loss / profit

Entrepreneurial Performance

1. Customer satisfaction

2. Employee loyalty

3 .Volume of sales

4 , Ability to create new products

5.Production volume

\section{References}

Anderson,U.,Forsgren,M..,Holm.2002. The Strategic Impact of External Networks : Subsidiary Performance and Competence Development In The Multinational Corporation. Strategic Management Decision Vol.23(11) pp.979-996

Angelen, Andreas., Flatten,Tessa Christina., Thalmann,Julia., Brettel,Julia. 2019. The Effect of Organizational Culture on Entrepreneural Orientation : A Comparason between Germany and Thailand. Journal of Small Business Management DOI : 10.1111/jsbm.12052. Vo.52 No.4 pp. 732-752

Chein,Shih,Yi.2014. Franchisor Resources, Spousal Resources, Entrepreuner Orientation and Performance in copuple-owned franchise outlet. Management Decision Vol.52 No.5 pp 916-933 ISSN 0025-147 DOI 10.118/MD.07-2013-0368

Chima,Okafor,Lawrence; Amodu,Ameh Abu. 2017.Social Network and Entrepreneurship Orientation among Student In Negerian Universities : A Study of Social Network Density and Proactiveness. International Journal of Business and Management Invention. ISSN (online) : 2319-8023, ISSN (print) : 2319-801X. Vol.6 No.7 pp33-41

Drucker,Peter.F.1994.Innovationand Entrepreunership,Practice and Principles. Gelora Aksara. Erlangga. Jakarta

Ferdinand, Augusty. 2014. Metode Penelitian Manajemen Pedoman Penelitian Untuk Penulisan Skripsi, Tesis dan Desertasi Ilmu Manajemn.Penerbit BP Undip Semarang

Ghozali,Imam.2011.Model Persamaan Struktural. Konsep Dan Aplikasi Dengan Program AMOS Ver.5. Semaranag : Badan Penerbit Universitas Diponegoro.

Glaser,Susan,R, Zamano; Sonia,Haker, Kenneth.1987. Measuring and Intrepeting Organizational Culture. Management CommunicationQuartely Vo.1 No.35 pp.173-198

Hair,J.F.JR,.Andersson,RE.,Tatham,R.L., Black,W.C.2014 Multivarite Data Analysis, Ftih Edition. International: Prentice-Hall,Inc

Hasibuan,Malayu.SP.2002. Manajemen Sumber Daya Manusia. Bumi Aksara. Jakarta.

Hair,Joseph F.Jr.,Anderson,Rolph E.,Tatham,Ronald L.,Black,William C.Multivariate 2014. Data Analysis Prentice Hall International Inc.

Kartono,Kartini.1994.Psikologi Sosial Untuk Manajemen Perusahaa dan Industri, PT.Raja Grafindo Persada. Jakarta..

Koesmono,Teman.2016.Mengelola Sumber Daya Manusia Perusahaan. Indomedia Pustaka, Yogyakarta.

2012. Faktor-faktor Perilaku Dalam Hubungan Industrial. Global Media.Surabaya

Koesmono,Teman 2019. Analysis of The Effect of Entrepreneurial Spirit, Entrepreneurial Rosurces, Entrepreunerial Orientation, Community Culture to Entrepreneurial Performance with Work Motivation as Mediating Variables on Micro, Small and Medium Enterprise in East Java, Indonesia. Journal of Culture , Society and Development ISSN-8400 An International Peer-reviewed Journal Vol.52. pp 46-61. 2019.

Kusnilawati,Nunik; Nurhidayati. 2020. Analisis Kinerja Wirausaha serta Variabel-Variabel Yang mempengaruhi. Jurnal Ilmiah Manajemen Bisnis dan Inovasi. Universitas SAM Ratulangi (JMBI UNSRAT). ISSN : 2356-3966 E-ISSN: 2621-2331. Vol.7 No.1 hal.139-149

Ludiya,Eka 2020. Pengaruh Komptensi Kewirausahaan dan Orientasi Kewirauisahaan Terhadap Kinerja Usaha Pada UMKM Bidang Fashion di kota Cimahi Jawa Barat. Jurnal Ilmu Manajemen \& Bisnis. ISSN 2337411X ISSN 2503-3522 (online) Vol.11 No.2

Lumpkin,G; Dess G..2001. Linking Two Demensions of Entrepreunerial Orentation To Firm Performance.The 
moderating Role of Environment and Industry Life Cycle . Journal Business Venturing. Vol.16(5) pp.429451

Luthans,Fred.1992 Organizational Behavior. Sixth Edition. Singapore.Mc Graww Hill Books Co.

Mariani, Wayan Eni; Wulantari,Nu Putu Ayu Siska. 2020. Kompetensi, Orientasi dan Minat Kewirausahaan Mahasiswa STIMK STIKOM Indonesia. ISSN : 2528-1208 (print) ISSN : 2528-2077 (online) Volume 5 No.2 hal. $45-50$

Miller,Danny; Peter,H.Freisen 2011. Innovation in Concervative and Entrepreneural Firms : Two Models of Strategic Momentum Public Administration Review Vol3 (1) pp 1-25

McShane,Steven L.; Glinov,Von.2003. Organizatioanl Behavior. McGraw-Hill Irwin.Americas Newyork

Neneh.B.N.2018. Customer Orientation And Performance : The Role of Networking Ties.African Journal Of Economic And Management Studies.Vol 4 pp. 67-89

Parida,Vinil; Weterbeg,Mats., Ylinenpaa,Hakan; Ronine Sari.2010. Exploring The effect of Network Configuration on Entrepreneurial Orientation and Firm Performance : an Empirical Study on Nev Ventures and Small Firms. Annuals of Inovation and Entrepreneurship. ISSN: (Print) 2000-7396 (online) Journal homepage:https://www.tandfonline.com/loi/Zale 20 Vo.1 No.1 pp.1-13

Purwanto,Heri., Trihudijatmanto.M.2018. Pengaruh Intensi berwirausaha, Orientasi kewirausahaan Terhadap Kinerja Usaha dengan Motivasi Sebagai Variabel Intervening Pada Sentra UMKM Cariga Di Wonosobo Thesis Universitas Sains Al-Qur'an (UNSIQ) hal 1-13

Rante, Yohanes.2010. Pengaruh Budaya Etnis dan Perilaku Kewirausahaan Terhadap Kinerja Usaha Mikro Kecil Agribinis di Propivinsi Papua Jurnal Manajemen dan Kewirausahaan Vol.12. No.12

Robbins,Stephen. P; Judge,Timothy A. 2015. Perilaku Organisasi. Penerbit Salemba Empat, Jakarta

Santoso,William; Supit Henky; Koesmono,Teman 2020. The Influenceof Organiuzational Culture, DunamicCapability and Social Network on Company Performance Witn Entrepreneural Orientation As Intervening variablein The Medium Busnisess Snack Industry nIn East Java. International Journal Of AdvancedResearch (IJAR).ISSN : 2320-5407.Vol.8 No.8 pp 536-544

Siswanto.2016. Pengantar Manajemen. Bumi Aksara, Jakarta

Solimun, 2017.Structural Equation Modelling (SEM) Lisreal dan Amos. Malang Fakultas MIPA Universitas Brawijaya

Sumantri,Bayu.2103 Pengaruh Jiwa Kewiraisahaan Terhadap Kinerja Usaha Wirausaha Wanita pada Industri Pangan Rumahan di Bogor. Theis Sekolah Pascasarjana Institut Pertanian Bogor, Program Studi Agribisnis.

Sugiyono.2010.Metode Penelitian Kuantitatif, Kualitatif dan R\&D. Penerbit Alfabeta Bandung

Suryana.2003. Kewirausahaan; Pedoman Praktis,Kiat dan Proses Menuju Sukses Berwirausaha.Penerbit Salemba Empat. Jakarta

Toyib,Jein Sriana. 2017. Pengarih Sumberdaya dan Orientasi Kewirausahaan Terhadap Kinerja Usaha Kecildan Menengah. Fakultas Ekonomi Dan Bisnis Universitas Papua. eMe Jurnal Manajemen Vol.12 No.2 hal.1-18

Trihudiyantmonto,M; Purwanto,Heri.2018 Pengaruh Motivasi, Kompetensi dan Orientasi Berwirausaha Terhadap Kinerja Usaha pada Sentra UMKM Pande Besi di Wonosobo Jawa Tengah. Journal of Economic, Management, Accounting and Technology (JEMATech) p-ISSN : 2622-8394 e-ISSN : 2622-8122 Vo.1 No.1. hal.31-40

Utama,Yosua Yudaikawira. 2017. Pengaruh Budaya dan keluarga Terhadap Orientasi Kewirausahaan Orang Muda Di Indoensia dan Malaysia.. Modus Journals Print.ISSN : 0852-1875 Online.ISSN : 2549-3789 Vol.29 No.2 hal. 157-175

Victor, Udeozor Chuckwuemeka. 2011 Influence of Culture on Entrepreneural Orientation and Performance of Negerian Firms. A Deseratation. The postgraduate school of Nottingham University Business School in partial fulfilment of the requirements for the degree of Master In Science pp. 1-70

Wickramaratne,Aruni., Kiminami,Akira; Yagi,Hironori. 2014. Entrepreneurial Compencies and Entrepreneurial Orientation of Tea Manufacturing Firms in Sri Lanka. Asian Social Science. ISSN1911-2017 E-ISSN 19112025 Vol.10 No.18 pp 50-62

Yuswani,Wiwik.2016.Pengaruh Budaya dan Stress Terhadap Motivasi Kerja dan Dampaknya Terhadap Kinerja Karyawan Pada PT.Kerinci Permata Motor Jambi. Jurnal Sinstech Polititeknik Indonesia Surakarta ISSN : 2355-5009 Vol.2 No.5 hal 1-10

Zahra,S.A.,I.Filatotchev, M.Wright. 2009. How Do Threshold Firms Sustain Corporate Entrepreunership. The Role of Boards and Absortive Capacity. Journal of Business Venturing. Vo.24.(6) pp 248-260 